\title{
Fishing in Salty Waters: Poverty, Occupational Saline Exposure, and Women's Health in the Indian Sundarban
}

\author{
Susmita Dasgupta ${ }^{1}$, David Wheeler ${ }^{2} \&$ Santadas Ghosh ${ }^{3}$ \\ ${ }^{1}$ Development Research Group, The World Bank, Washington DC, USA \\ ${ }^{2}$ Consultant, The World Bank, Washington DC, USA \\ ${ }^{3}$ Department of Economics and Politics, Visva-Bharati, West Bengal, India \\ Correspondence: Susmita Dasgupta, Development Research Group, MSN: MC-3-308, The World Bank, 1818 H \\ Street, Washington, DC 20008, USA.
}

Received: October 16, 2021

Accepted: December 1, $2021 \quad$ Online Published: December 17, 2021

doi:10.5539/jms.v12n1p1

URL: https://doi.org/10.5539/jms.v12n1p1

\begin{abstract}
Collecting wild tiger prawn seedlings, also known as prawn post-larvae (PL), from rivers and creeks is an important occupation for more than 100,000 poor women in India's Sundarban estuarine delta. Prawn PL collecting requires many hours of immersion in saline river water. This paper uses a large household survey to explore the determinants of poor women's engagement in this occupation and the health impacts. The results reveal high significance for two variables: (i) the opportunity wage, proxied by years of education and (ii) child-care demands, proxied by the household child-dependency ratio. Together, these variables are sufficient to distinguish between women who have no engagement with prawn PL collecting and those with many years of engagement. The probability of self-reported health problems is also significantly higher for women with more saline exposure from prawn PL collecting and whose drinking water is from tube wells with higher salinity.
\end{abstract}

Keywords: health perception, occupational choice, poverty/environment nexus, salinity exposure, Sundarban, women's education

\section{Highlights}

- Analysis of new household survey data reveals a significant poverty/environment nexus that affects mainly older, less-educated women in the Indian Sundarban who engage in prawn post-larvae (PL) collection.

- Previous research paid little attention to women who work year-round in this occupation, despite the health risks from long-term saline immersion and the physical risk of crocodile attacks.

- Women engaged in this activity report more health problems compared to their counterparts who engage in otherwise comparable low-wage economic activities, such as fishing and agriculture.

- Appropriate policies can help by subsidizing healthier employment alternatives for poor women in this region or promoting community management and financing of prawn PL collection.

- Educational progress will reduce the number of women who engage in prawn PL collection in the coming years.

\section{Introduction}

The Sundarban coastal region of India's West Bengal state is the spawning ground for $90 \%$ of the aquatic taxa of India's northeastern coast, including 172 fish species, 20 prawn species and 44 crab species (Chandra \& Sagar, 2003) (Note 1). The area is also home to some of the world's poorest and most vulnerable people. Poor women are often seen wading waist-deep for hours in the salty tidal rivers and creeks, dragging triangular nets that collect the seedlings of wild tiger prawn (Penacus monodon) or prawn post-larvae (PL) (Figure 1). The yield from this activity (Figure 2) is sold to aquaculture farms. It varies by season and lunar cycle; a good day's catch may earn 300-500 Indian rupees (US\$ 4-7). Demand and prices were higher in the 1990s, and the market has since shifted toward Venami, an imported species whose seedlings are supplied by hatcheries. At the same time, increased rural wages have diverted male workers to other occupations, leaving prawn PL collection to women whose job opportunities are more restricted. Although engagement in prawn PL catching has declined since the 1990s, this occupation still employs at least 100,000 women in the Indian Sundarban. The seedling population 
peaks in April-May and August-September, but many local women work year-round despite constant immersion in salty water and the risk of crocodile attacks.

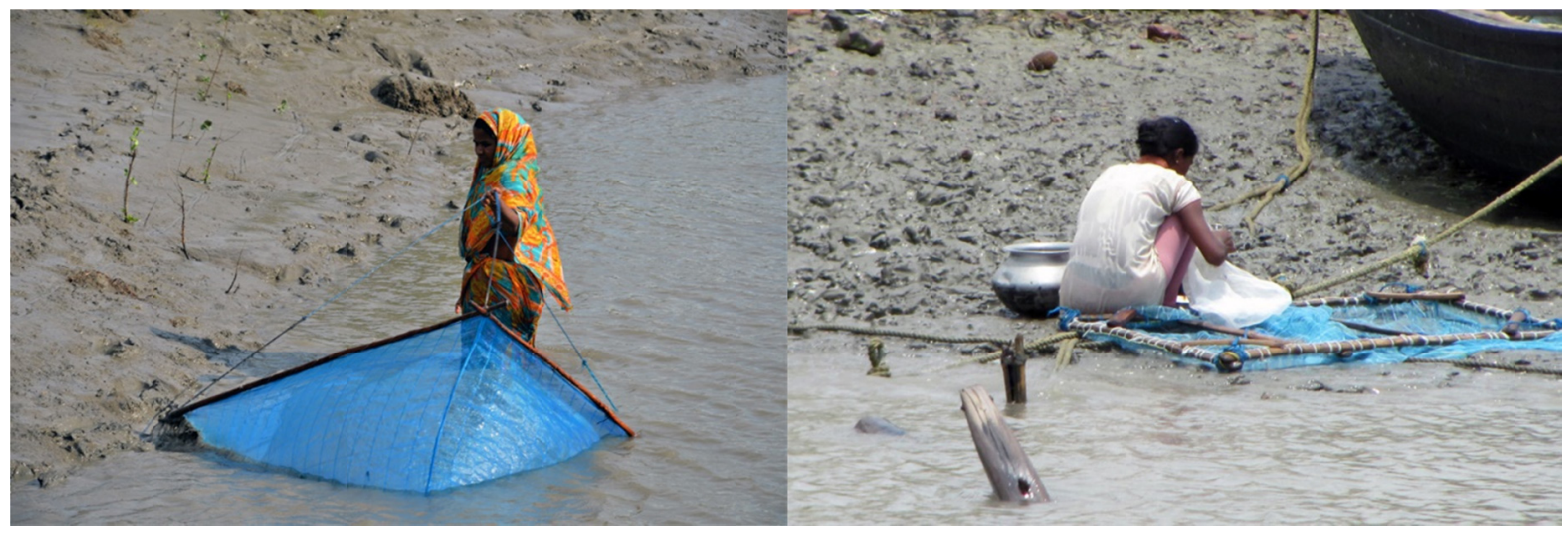

Figure 1. Prawn PL catching in Shyamnagar, Satkhira (left) and sorting in Hingalganj, North 24 Parganas (right) Note. C Md. IstiakSobhan/ World Bank (left); C SantadasGhosh (right). Reproduced with permission. Further permission required for reuse.

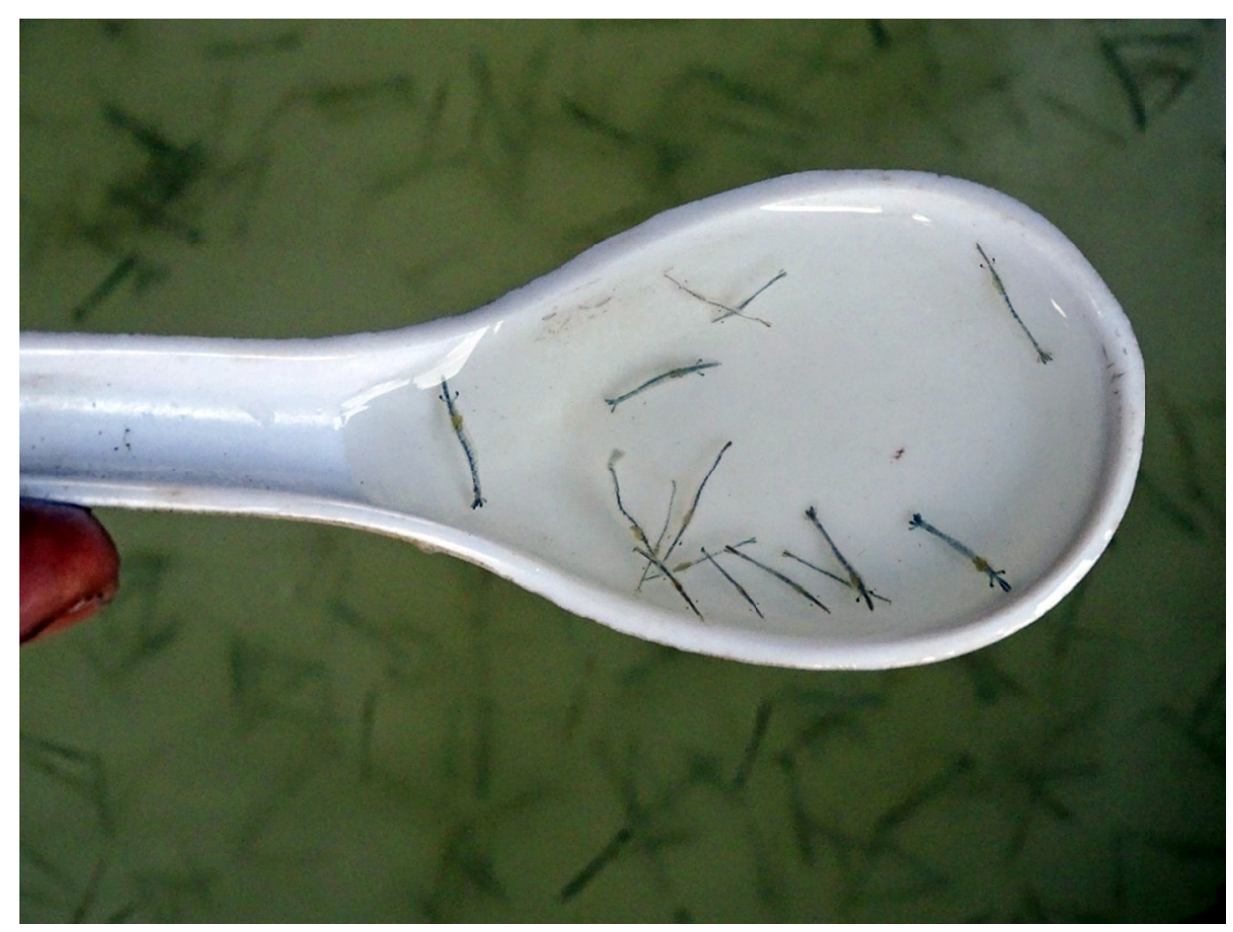

Figure 2. Prawn PL collected from the wild

Note. (C) ParitoshGiri. Reproduced with permission. Further permission required for reuse.

Although poor women have collected prawn PL since the early 1980s, studies of their lives and working conditions have been rare because access to the Sundarban region is difficult at best and many settlements are isolated. Utilizing an extensive field survey, this paper contributes to understanding Sundarban women's socioeconomic conditions, occupational choices, and the health impacts of occupational exposure.

\section{Research Summary}

In the first stage of the work, described more fully in Section 3.1, 16 focus group discussions were conducted with the local leaders of Women's Self-Help Groups to understand women's occupational choices in a spatially-dispersed set of Sundarban villages. The discussions focused particularly on women who fish in saline water, their average exposure time, and health problems. As described in Section 3.3, the results were used to develop and administer a survey of 4,027 individuals in 901 households and 64 locales spread across the 
Sundarban. Sections 3.5.2 and 3.5.3 use the survey data to conduct an econometric analysis of the links between women's socioeconomic status, occupational choices, and reported health outcomes. To the best of the authors' knowledge, this is the first statistical analysis that provides an in-depth view of occupation choice economics and its health implications for women in the Sundarban. It is hoped that the findings will inform Indian policymakers who can promote new business lines, skills training, and subsidized credit to improve the livelihoods and health of these vulnerable women. This study will also contribute significantly to the literature on gender, occupational choice, and environmental health among marginalized peoples in the Sundarban and elsewhere.

\section{Methodology}

\subsection{Survey Preparation}

Figure 3 displays the 16 secondary administrative units (gram panchayats) where initial discussions were conducted with Women's Self-Help Groups during December 2018-January 2019. The selected locations span the Indian Sundarban region, at widely-varying distances from the rivers and creeks where prawn PL collection occurs. These discussions provided the basis for design of the survey described in Section 3.3. They revealed that collection remains particularly widespread in the Hooghly-Matla estuarine complex, varying across locales and seasons as prawn seedlings fluctuate with changes in water salinity. Poor women with limited job opportunities predominate, spending long periods in salty water under the constant risk of crocodile attacks. Participants in all 16 focus groups were unanimous in associating many health problems with extended saline exposure.

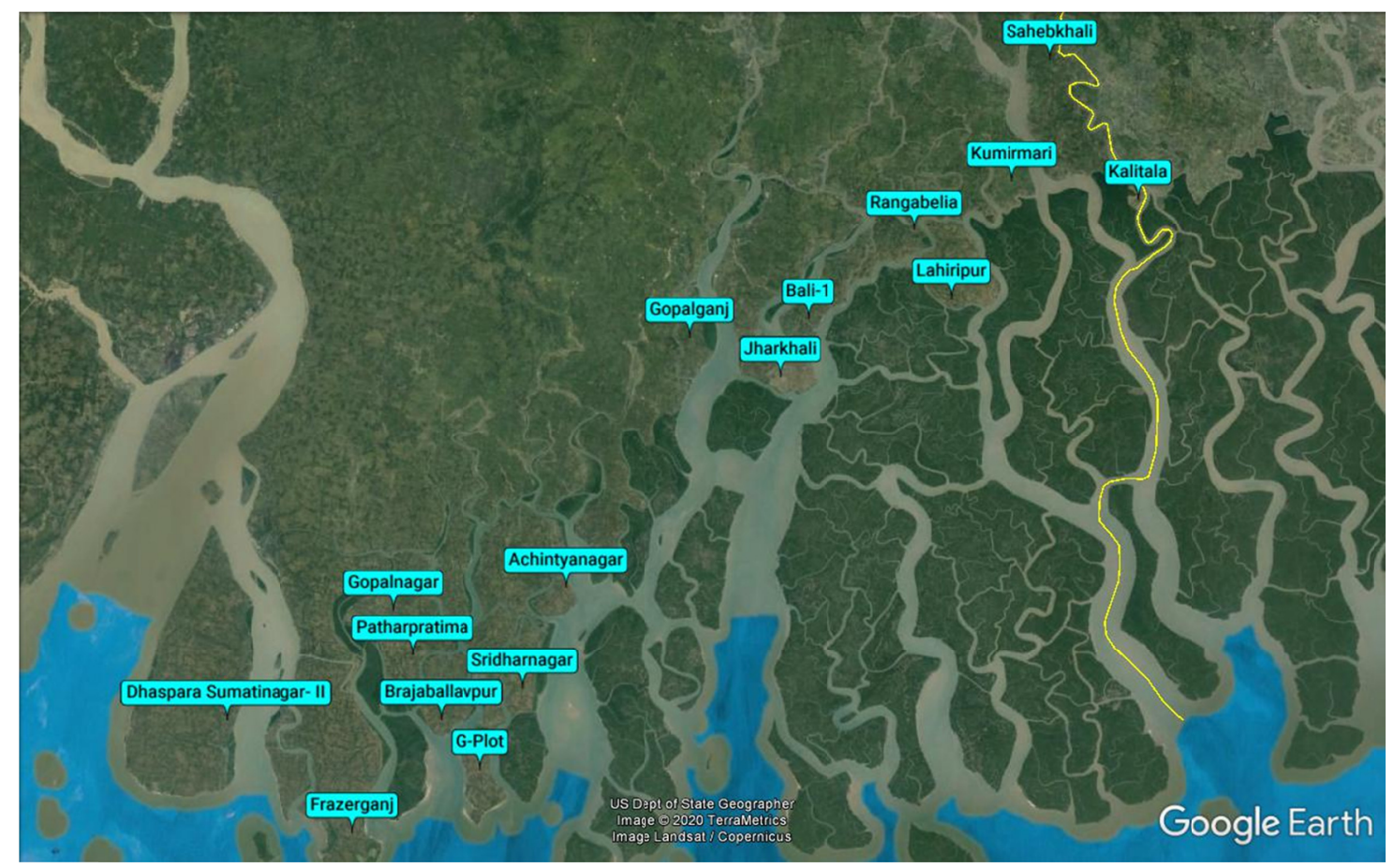

Figure 3. Sites of focus group discussions in the Indian Sundarban

Source: https://earth.google.com/with authors' marking of places.

The discussions revealed that, among the 16 sites studied, Sahebkhali (the northernmost site in Figure 3), situated on the Raimangal River, has the highest concentration of prawn PL catchers for both environmental and economic reasons. The water is less saline because the river's headstream has continual freshwater replenishment. Lower salinity yields a greater concentration of tiger prawn seedlings. At the same time, many inland prawn farms are located in nearby Hingalgunj, so time and transport cost to market are lower for catchers in this area.

\subsection{Development of Local Salinity Profiles}

The discussions described in Section 3.1 also provided a template for measuring water salinity in the region. Data on water salinity in the Indian Sundarban are scarce. Since this variable is a critical determinant of prawn PL supply, a baseline profile was generated for the study area with water samples from 50 locations in surveyed 
villages near the Bidya, Matla, Hooghly, and Raimangal rivers. Samples of tube-well water were also collected for 50 hamlets in the 16-gram panchayats covered by the study.

\subsection{Survey Implementation}

The survey interviewed 4,027 individuals from 901 households in 63 locales spread across the region during February-May 2019 (Appendix A). The household sample was drawn from locales in the 16-gram panchayatssurrounding the Sundarban Reserve Forest, where the discussions described in Section 3.1 were held. The area spans the inhabited part of the region from its northeast to southwest corner (Figure 3). Women's Self-Help Groups in these gram panchayats facilitated the selection of hamlets with varying levels of prawn PL collection. An average of 4 hamlets were selected from each gram panchayat to ensure variation in the concentration of PL collectors. Approximately 15 households were selected in each hamlet, with scale of land ownership as the main stratification variable.

For the health component of the survey and the econometric analysis described in Section 3.5.3, focus group women and local doctors were consulted to establish a list of 69 relatively common ailments. Information on their incidence in the female population is arguably unique because, to the authors' knowledge, this is the only large-scale, spatially-representative survey that has been administered in the Indian Sundarban. The area is remote; many locales are isolated and unreceptive to outsiders. The survey has been possible because one of the authors conducted extensive research in the Sundarban and is well-known to residents of the region. Tables 1 and 2 show that the sampling design ensured broad representation by gender, age, and education.

Table 1. Sundarban survey participants

\begin{tabular}{llll}
\hline & Gender & & \\
\cline { 2 - 3 } Age & Male & Female & Number \\
\hline $0-5$ & 154 & 141 & 295 \\
$6-15$ & 322 & 339 & 661 \\
$16-30$ & 613 & 596 & 1,209 \\
$31-50$ & 562 & 588 & 1,150 \\
$51-65$ & 295 & 226 & 521 \\
$66+$ & 103 & 88 & 191 \\
Total & $\mathbf{2 , 0 4 9}$ & $\mathbf{1 , 9 7 8}$ & $\mathbf{4 , 0 2 7}$ \\
\hline
\end{tabular}

Source: The authors.

Table 2. Sundarban survey participants, by gender and years of schooling

\begin{tabular}{llll}
\hline & \multicolumn{2}{l}{ Gender } & \\
\cline { 2 - 3 } Years of schooling & Male & Female & Number \\
\hline 0 & 289 & 453 & 742 \\
1 & 199 & 226 & 425 \\
2 & 66 & 75 & 141 \\
3 & 73 & 74 & 147 \\
4 & 199 & 175 & 374 \\
5 & 166 & 132 & 298 \\
6 & 110 & 110 & 220 \\
7 & 113 & 93 & 206 \\
8 & 214 & 152 & 366 \\
9 & 161 & 129 & 290 \\
10 & 230 & 195 & 425 \\
11 & 25 & 29 & 54 \\
12 & 117 & 90 & 207 \\
13 & 10 & 12 & 22 \\
14 & 7 & 6 & 13 \\
15 & 52 & 14 & 66 \\
16 & 11 & 9 & 20 \\
17 & 2 & 0 & 2 \\
18 & 5 & 4 & 9 \\
Total & $\mathbf{2 , 0 4 9}$ & $\mathbf{1 , 9 7 8}$ & $\mathbf{4 , 0 2 7}$ \\
\hline
\end{tabular}

Source: The authors. 
Survey sampling was also designed for econometric analysis (Section 3.5) by including significant representation for a spatially-dispersed population of working-age women, identified in this exercise as 15-65 years of age, who engage in river fishing. Figure 4 provides two dimensions of information in this context. First, it shows that the survey spans the Sundarban region, thereby capturing many dimensions of environmental, social, and economic variation. Second, the database captures great variation in the intensity of women's engagement. The sample includes locales with representation between 0 and 55 percent for women engaged in prawn PL catching, crabbing, and fishing (indicated by the color-coded dots). Figure 4also shows that the full range of variation is preserved both within and across the sub-regions. Appendix B identifies the locales displayed in Figure 4, along with the number of working-age women surveyed in each locale and the percentage of those whose main occupation is prawn PL catching, crabbing, or fishing.

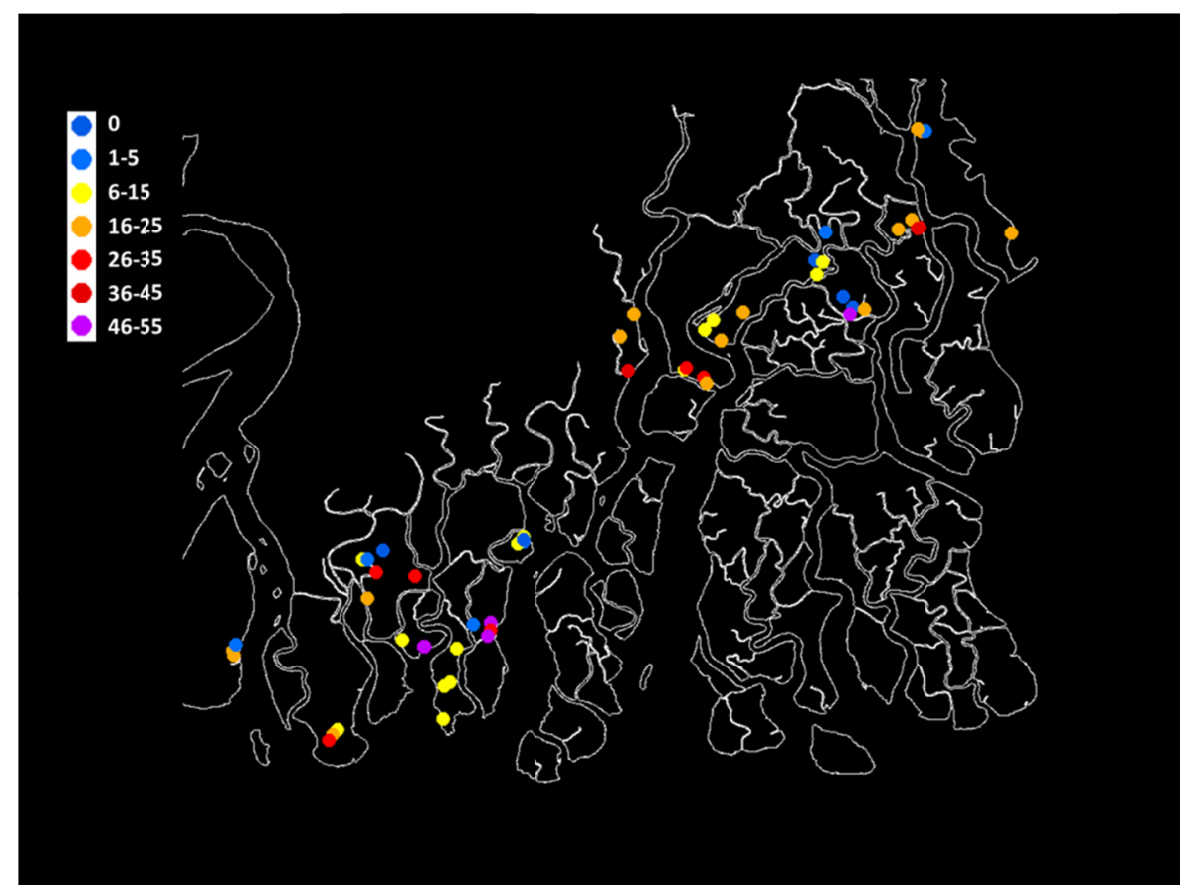

Figure 4. Sundarban survey locales, showing percentage of working-age women in prawn PL collection, crabbing, and fishing

Source: The authors.

\subsection{Measurement of Water Salinity}

Using the sampling template introduced in Section 3.2, water salinity was measured using the AZ8371 salinity tester, a high-precision portable monitor that also measures water temperature. Before field samples were collected, the instrument was calibrated with distilled water, packaged drinking water, common drinking water from tube wells, and saline water created by mixing salt with packaged drinking water.

Table 3 summarizes the overall results from field monitoring of tube well and river water in the study area, as described in Section 3.2. Figure 5 provides geographic detail, showing that river-water salinity in parts of the Indian Sundarban exceeds 25 parts per thousand (ppt) (Figure 5a). Salinity beyond the potability standard of 1 ppt is also common in groundwater, which is the sole source of drinking water in populated areas of the Indian Sundarban (Figure 5b).

Table 3. Water salinity measures

\begin{tabular}{lllll}
\hline Salinity (ppt) & Minimum & Maximum & Mean & Median \\
\hline Tube well and/or water taps (sampled from various villages) & 0.41 & 2.66 & 0.87 & 0.84 \\
River water (sampled at locations nearest villages) & 13 & 27 & 21.94 & 22.55 \\
\hline
\end{tabular}

Note. Water is not potable if salinity exceeds 1 part per thousand (ppt).

Source: The authors. 


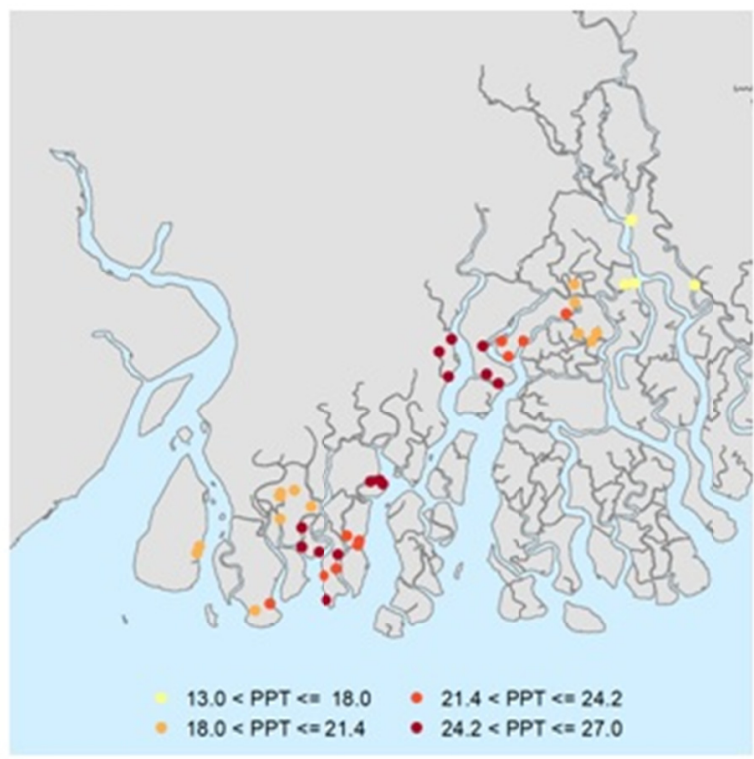

a. River water

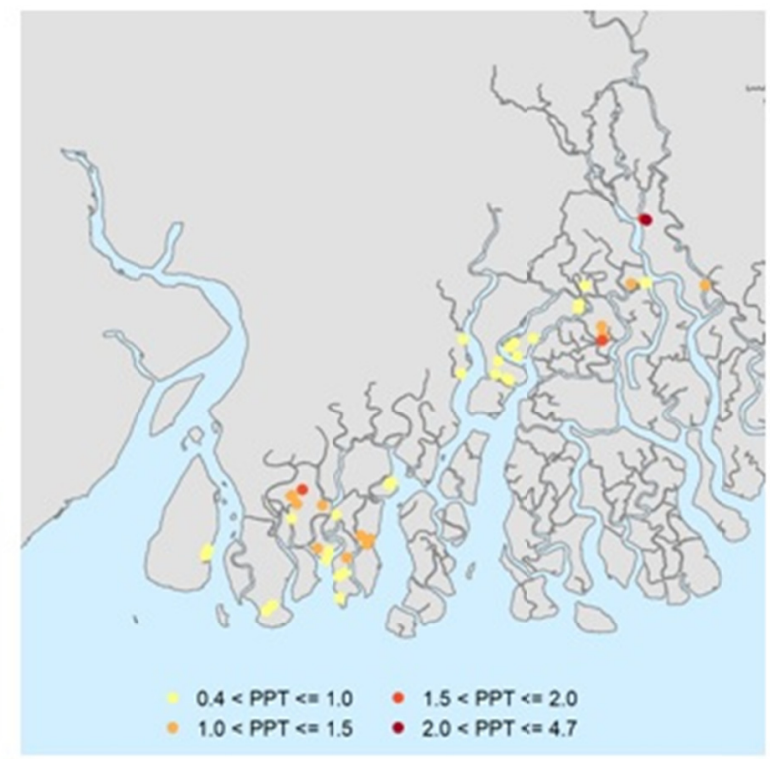

b. Tubewell water

Figure 5. Water salinity in the Indian Sundarban, February-May 2019

Source: The authors.

\subsection{Determinants and Impacts of Female Prawn PL Collection}

The survey exercise created a detailed sampling frame for each of the selected hamlets. After determining the status of prawn PL collection for all households in the hamlets, the proportion of collecting households was estimated in the surrounding census blocks. To estimate total households engaged in prawn PL collection, each block's proportion was multiplied by its total households in the 2011 Indian Census (GOI 2011).

\subsubsection{Female Participation}

Table 4 displays the elements used to estimate that 97,437 households have women engaged in prawn PL collection in the Indian Sundarban.

Table 4. Estimated number of households with female prawn PL collectors in the Indian Sundarban

\begin{tabular}{|c|c|c|c|c|c|c|}
\hline \multirow[t]{2}{*}{ District } & \multirow[t]{2}{*}{ Block } & \multirow{2}{*}{$\begin{array}{l}\text { Rural } \\
\text { house-holds } \\
\text { (total no.) }\end{array}$} & \multicolumn{3}{|c|}{ Households in the sampling frame } & \multirow[b]{2}{*}{$\begin{array}{l}\text { Estimated prawn PL } \\
\text { collecting households in } \\
\text { block }\end{array}$} \\
\hline & & & No. listed & $\begin{array}{l}\text { Prawn PL } \\
\text { collecting } \\
\text { households(no.) } \\
\end{array}$ & $\begin{array}{l}\text { Prawn PL } \\
\text { collecting } \\
\text { households(\%) } \\
\end{array}$ & \\
\hline North 24 & Hingalganj & 42,117 & 220 & 23 & 10.5 & 4,403 \\
\hline \multirow[t]{2}{*}{ Parganas } & Sandeshkhali-I & 37,344 & \multirow{2}{*}{\multicolumn{2}{|c|}{ (Not included in sample) }} & 10.5 & 3,921 \\
\hline & Sandeshkhali-II & 37,771 & & & 10.5 & 3,966 \\
\hline South 24 & Basanti & 69,295 & 279 & 94 & 33.7 & 23,347 \\
\hline \multirow[t]{5}{*}{ Parganas } & Gosaba & 58,197 & 994 & 252 & 25.4 & 14,754 \\
\hline & Kultali & 45,099 & 337 & 73 & 21.7 & 9,769 \\
\hline & Namkhana & 41,433 & 180 & 31 & 17.2 & 7,136 \\
\hline & Patharpratima & 69,641 & 1,257 & 395 & 31.4 & 21,884 \\
\hline & Sagar & 43,716 & 180 & 34 & 18.9 & 8,257 \\
\hline Total no. & & & & & & 97,437 \\
\hline
\end{tabular}

Note. The 2011 District Census Handbook (North 24 Parganas and South 24 Parganas) was the source for the total number of rural households. Source: The authors.

\subsubsection{Occupational Choice: Engagement in Prawn PL Collection}

The analysis of prawn PL catching as an occupational choice was conducted in three steps, using the survey data described in Section 3.3. The first step estimated an econometric model that relates women's years of 
engagement in prawn PL collection to their age, opportunity wage (proxied by education), household assets, and child-care demands, indexed by the household dependency ratio. Determining this ratio involved experimentation with alternative numerators (children $0-5,0-10$, and $0-17$ ) and denominators (women 18-60 and $18+$ ). While all yielded significant results, the best fit was provided by children $0-10$ divided by women $18-$ 60. Prior expectations were that engagement would be positively related to age and negatively related to years of education, household wealth, and the dependency ratio. The measure of wealth is a count of household assets identified by the survey instrument. The equation is expressed as follows:

$$
\begin{aligned}
& S_{i}=\alpha_{0}+\alpha_{1} A_{i}+\alpha_{2} E_{i}+\alpha_{3} H_{i}+\alpha_{4} D_{i}+\varepsilon_{i} \\
& \text { (Expectations: } \alpha_{1}>0 ; \alpha_{2}, \alpha_{3}, \alpha_{4}<0 \text { ), }
\end{aligned}
$$

where, for female $i, S_{i}$ equals the years of engagement in prawn PL collection, $A_{i}$ stands for age, $E_{i}$ represents years of education, $H_{i}$ equals the household asset count, $D_{i}$ is the dependency ratio (children 0-10/women 18-60), and $\varepsilon$ is a random error term (which may incorporate spatial autocorrelation).

The second step explored the implications by using the regression estimates to predict years of prawn PL catching at varying levels of education and the dependency ratio for a woman 40 years of age who lives in a household with the mean asset count. Finally, to provide additional insights for policy, the third step fitted a spline regression to the relationship between female age and education in the survey data.

Table 5 reports results for equation (1) with four estimators: standard OLS; OLS with robust standard errors; GLS, which allows for differences in error variances for hamlet-level sample clusters; and Spatial, which incorporates spatial autocorrelation among sample observations. In the latter case, the sample size is reduced by unreported location coordinates and elimination of duplicate location observations for women in the same household. All variables have the expected signs: age, education, and the dependency ratio have high significance. However, no significance has been found for household assets. The effect of education is particularly powerful, with an estimated decline of .73 years of prawn PL collection for each additional year of schooling in the large-sample results.

Table 5. Determinants of prawn PL exposure

\begin{tabular}{lllll}
\hline Variable & OLS & Robust & GLS & Spatial \\
\hline Age & 0.172 & 0.172 & 0.172 & 0.211 \\
& $(5.15)^{* *}$ & $(4.73)^{* *}$ & $(5.80)^{* *}$ & $(4.31)^{* *}$ \\
Years of education & -0.728 & -0.728 & -0.728 & -0.654 \\
& $(7.10)^{* *}$ & $(8.23)^{* *}$ & $(6.92)^{* *}$ & $(4.84)^{* *}$ \\
Household asset count & -0.099 & -0.099 & -0.099 & 0.018 \\
& $(0.77)$ & $(0.79)$ & $(0.69)$ & $(0.10)$ \\
Child dependency ratio & -1.834 & -1.834 & -1.834 & -1.731 \\
& $(3.36)^{* *}$ & $(4.01)^{* *}$ & $(4.72)^{* *}$ & $(2.59)^{* *}$ \\
Constant & 5.779 & 5.779 & 5.779 & 3.605 \\
& $(3.32)^{* *}$ & $(3.52)^{* *}$ & $(3.72)^{* *}$ & $(1.46)$ \\
Observations & 770 & 770 & 770 & 477 \\
R-squared & 0.19 & 0.19 & 0.19 & \\
\hline
\end{tabular}

Note. Dependent variable $=$ years of prawn PL collection. Absolute values of $\mathrm{t}$ statistics are shown in parentheses; significance level: $*=5$ percent, $* *=1$ percent.

Source: The authors.

Table 6 provides a summary of education and dependency ratio effects, predicting years of prawn PL collection for a woman 40 years of age who lives in a household with the mean asset count. As shown, great variation is attributable to education and the child dependency ratio. The expected prawn PL collection years are effectively 0 for a woman with 12 years of education in a household with a dependency ratio of 2 or more. Conversely, expected collection years are 12.1 for a woman with no formal education who lives in a household with no children younger than 11 . 
Table 6. Predicted years of prawn PL collection

Source: The authors.

\begin{tabular}{llll}
\hline Dependencyratio & \multicolumn{3}{l}{ Years of education } \\
\cline { 2 - 4 } & $\boldsymbol{0}$ & $\mathbf{6}$ & $\mathbf{1 2}$ \\
\hline 0.0 & 12.06 & 7.60 & 3.13 \\
0.5 & 11.14 & 6.68 & 2.21 \\
1.0 & 10.22 & 5.76 & 1.29 \\
1.5 & 9.30 & 4.84 & 0.37 \\
2.0 & 8.38 & 3.92 & 0 \\
3.0 & 6.54 & 2.08 & 0 \\
\hline
\end{tabular}

Figure 6 presents the fitted spline regression of the relationship between female age and education in the survey data. As the regression results indicate, the significantly-higher educational status of young women compounds the age-related likelihood that they will not engage in prawn PL collection.

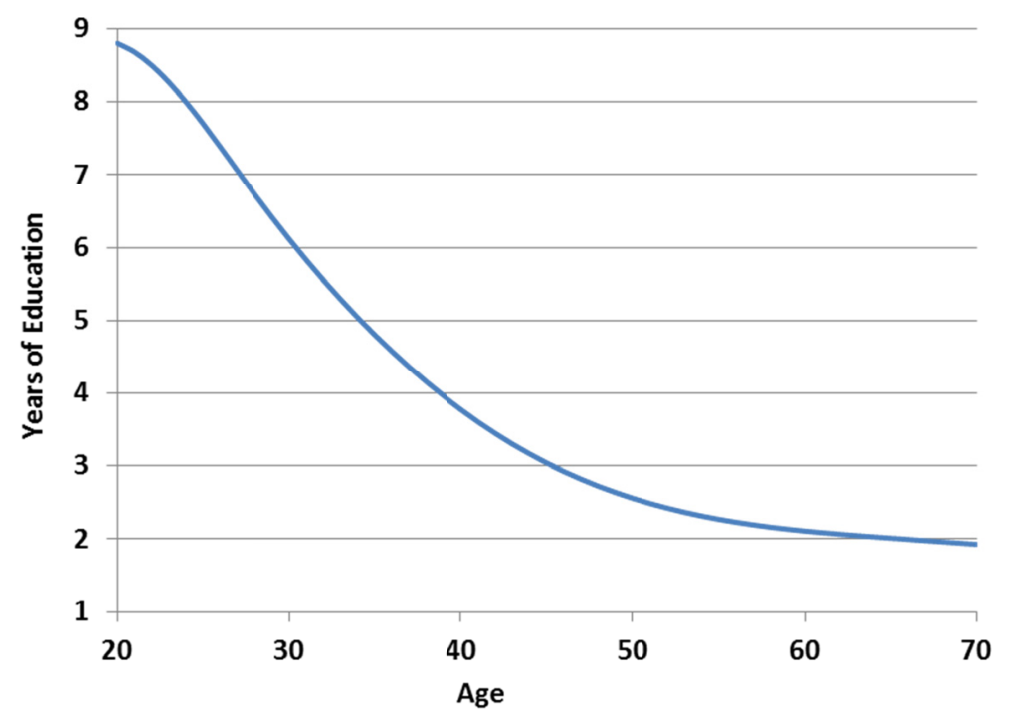

Figure 6. Female years of education versus age

Source: The authors.

\subsubsection{Environmental Health Impacts}

Health impacts were assessed for 69 self-reported ailments identified by the survey, as described in Section 3.3. The focus on prawn PL collection made it particularly important to distinguish between the health impacts of this activity and otherwise-comparable activities that may be chosen by women with similar socioeconomic circumstances. Accordingly, the exercise included years of engagement in crabbing and fishing, which occur in similar riverine environments but involve less immersion in saline water. Engagement in agriculture was also included as a control.

Age, education, and household assets were incorporated, given that these variables could have significant direct effects on health, as well as indirect effects via prawn PL collection. The measure of local tube well salinity was also included, since tube wells are the main source of drinking water in the study region. Although river water salinity was measured near the villages, an appropriate control for river salinity where catching occurs was not possible because prawn PL exposure is measured in years and the survey exercise could only gather single measures of river salinity in each fishing area. Because measures of river salinity are also highly stochastic and seasonal, expectations for the significance of this variable were never high. Preliminary econometric experiments revealed the limited river-salinity measure as insignificant in all cases, so it was excluded from the final estimation exercise.

The health impact equation is specified as follows: 


$$
P_{i}=\beta_{0}+\beta_{1} S_{i}+\beta_{2} C_{i}+\beta_{3} F_{i}+\beta_{4} L_{i}+\beta_{5} A_{i}+\beta_{6} E_{i}+\beta_{7} H_{i}+\beta_{8} T_{i}+\varepsilon_{i}
$$

(Expectations: $\beta_{1}, \beta_{2}, \beta_{3}, \beta_{4}, \beta_{5}, \beta_{8}>0 ; \beta_{6}, \beta_{7}<0$ ),

where, for female $i, P_{i}$ equals the probability of reporting a significant ailment and $S_{i}, C_{i}$, and $F_{i}$ represent the respective years of engagement in prawn PL collection, crabbing, and fishing. $L_{i}$ equals 1 if the primary occupation is agriculture and 0 otherwise. $A_{i}$ stands for age, $E_{i}$ equals years of education, $H_{i}$ is the household asset count, $T_{i}$ represents tube well salinity, and $\varepsilon$ is a random error term.

Equation (2) was estimated using logistic regression. The results of the regression, reported in Table 7, were used to explore the ceteris-paribus relationships between health, engagement in prawn PL collection and drinking-water salinity. Since the survey exercise collected reports on 69 specific ailments from each woman surveyed, the health impact of prawn PL collection was explored in more detail by re-estimating equation (2) for each reported ailment. In each case, the dependent variable had a value of 1 if a woman reported the ailment and 0 otherwise. Results are available from the authors on request.

The three columns of Table 7 report estimate for standard logit; GLS logit, which allows for differences in error variances for hamlet-level sample clusters; and logit with robust standard errors. The first four variables provide evidence on whether extensive saline immersion during prawn PL collection has a greater health impact than engagement in otherwise-similar riverine activities (i.e., crabbing and fishing, as well as agriculture). The results strongly suggest that saline immersion has a powerful independent effect. While years of prawn PL collection has a positive, highly-significant effect on the probability of a reported ailment, the three comparator variables are insignificant. As expected, the results indicate that older women are more likely to report ailments, all else being equal. Somewhat surprisingly, however, education is not found to be significant aside from its powerful indirect effect via engagement in prawn PL collection. As before, no significant effect is found for household wealth. There is a large, significant effect for drinking-water salinity.

Table 7. Determinants of general ailments

\begin{tabular}{llll}
\hline Variable & Logit & Logit GLS & Logit Robust \\
\hline Prawn PL collection years & 0.029 & 0.029 & 0.029 \\
Crabbing years & $(3.12)^{* *}$ & $(2.94)^{* *}$ & $(2.95)^{* *}$ \\
Fishing years & -0.006 & -0.006 & -0.006 \\
& $(0.58)$ & $(0.47)$ & $(0.51)$ \\
Agriculture as primary occupation & 0.019 & 0.019 & 0.019 \\
Age & $(1.60)$ & $(1.62)$ & $(1.59)$ \\
& -0.023 & -0.023 & -0.023 \\
Years of education & $(0.13)$ & $(0.15)$ & $(0.13)$ \\
& 0.033 & 0.033 & 0.033 \\
Household asset count & $(4.13)^{* *}$ & $(4.00)^{* *}$ & $(3.67)^{* *}$ \\
Tube-well salinity & -0.018 & -0.018 & -0.018 \\
& $(0.75)$ & $(0.69)$ & $(0.75)$ \\
Constant & -0.006 & -0.006 & -0.006 \\
& $(0.20)$ & $(0.20)$ & $(0.19)$ \\
Observations & 0.288 & 0.288 & 0.288 \\
\hline
\end{tabular}

Note. Dependent variable = probability of reporting any of the surveyed ailments. Absolute values of $\mathrm{t}$ statistics are shown in parentheses; significance level: $*=5$ percent, $* *=1$ percent.

Source: The authors.

Figure 7 displays the relationships between health and engagement in prawn PL collection and drinking-water salinity, all else being equal. To produce Figure 7a, ailment-reporting probabilities were predicted for years of prawn PL collection in the sample range, controlling for other activities ( 0 years for crabbing and fishing; 0 for agriculture as primary occupation; age (40); education (6 years); mean household asset count; and mean tube well salinity. As shown, an increase in prawn PL collection from 0 to 25 years leads to a 27.5 percent increase in reported ailment probability (from .570 to .727 ). Figure $7 \mathrm{~b}$ predicts ailment reporting probabilities for tube well water salinity in the sample range, controlling for other activities (10 years for prawn PL collection; 0 years for 
crabbing and fishing; 0 for agriculture as primary occupation; age (40); education (6 years); and mean household asset count. An increase in tube-well salinity from 0.41 to 4.20 leads to a 35.6 percent increase in reported ailment probability (from .604 to .819).

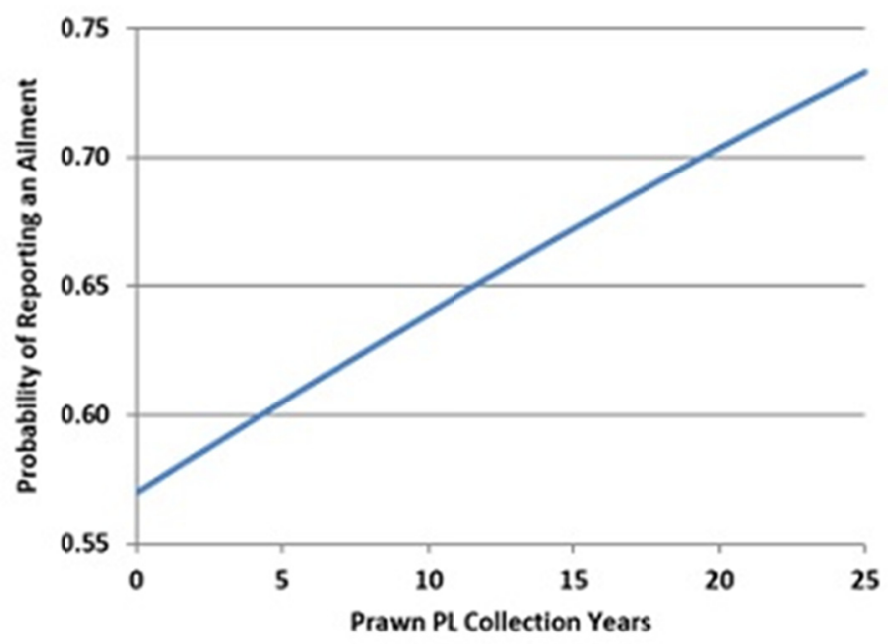

a Engagement in prawn PL collection

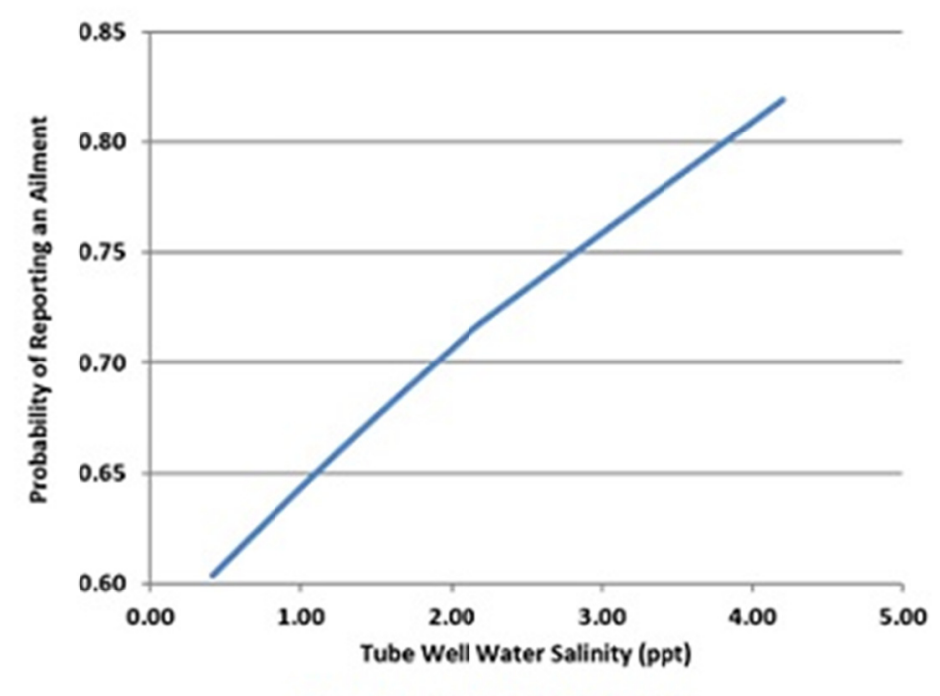

b. Tube-well drinking water

Figure 7. Health impacts of river and tube-well salinity

Source: The authors.

\section{Discussion of Results}

\subsection{Gender in Prawn PL Collection}

Although prawn PL collection by women is widespread in the Indian Sundarban, in-depth studies have been scarce because information is difficult to collect for this isolated region. A study carried out by the Central Institute of Brackish water Aquaculture, Madras, India noted that wild prawn PL have been collected in the mangrove ecosystem of the Indian Sundarban since the early 1980s, when West Bengal intensified efforts to develop coastal aquaculture, especially shrimp farming, during India's sixth five-year plan (Banerjee \& Singh, 1993). Until the current study, however, an estimate of total collectors in the region was not available. 
The estimate of female prawn PL engagement in Table 4 is believed to be very conservative, given several potential sources of downward bias. First, it assumes engagement by one woman per household, although many households have more than one female participant in prawn PL collection. Second, the exercise has focused on only nine blocks in the Sundarban, while prawn PL collection also occurs in other delta areas like the adjoining district of Midnapore. Third, the estimates use household counts at the block level from the 2011 Census of India (GOI, 2011), which is the latest one available. However, the number of households has undoubtedly grown since then. In addition, one source of variation can be identified that may bias the estimate either upward or downward. After the initial focus group discussions, sample hamlets were selected at the gram panchayat level to provide representation for cases with high, medium, and low concentrations of prawn PL collectors. However, there was no basis for determining the overall proportion of hamlets within each class.

\subsection{The Economics of Occupational Choice}

The findings on the economics of occupational choice, summarized in Table 5, show that women are highly responsive to opportunity wages and child-care demands in determining whether to engage in prawn PL collection. The resulting engagement is essentially zero for secondary-educated women with high child-care demands and very substantial for women with no formal education and no child-care demands. These findings are in line with other studies of the impacts of child-care responsibilities on mothers' decision to work (Kornstad \& Thoresen, 2007; Asai et al., 2015). However, the existing literature focuses heavily on women's occupational choices in high-income countries. The current research provides one step toward filling the gap for poor women in rural Asia.

Surprisingly, the findings indicate that family wealth has no significant effect on women's engagement in prawn PL collection. Given the widespread view that this work entails health hazards, one might expect women in wealthier families to avoid it, all else being equal. The result may be affected by simultaneity bias, since women engage in prawn PL collection to augment family income and wealth. The implications have been checked by re-estimating the prawn PL collection equation with the asset count excluded, and the results are otherwise unchanged.

\subsection{Environmental Health}

The health impact of prolonged immersion in saline water has received little attention in the research literature, perhaps because such exposure is rare in developed countries. Until now, evidence for the Sundarban region has been scattered and anecdotal. But the women in the preliminary focus group interviews, described in Section 3.1, were unanimous in associating health problems with long hours of exposure to saline water in the rivers. The women's belief about the association is important, because their risk perception influences decisions about whether, and how much, to engage in saline-immersive activities. Therefore, the survey responded by asking detailed questions about women's saline-immersive fishing activity and their health status.

As the results in Table 7 show, women who engage in saline-immersive prawn PL collection report significantly more health problems than their counterparts who engage in otherwise-comparable low-wage economic activities. These health problems are clustered in a subset of the 69 ailments enumerated by the survey: irregular menstruation; problems with eyesight; gastric pain; pain in the hands, legs, and knees; skin allergies; and itching. The findings of the research align with previous field studies by B. Kanjilal, reported in Jena (2018), which suggest that prolonged contact with salty water by poor women results in a higher incidence of skin diseases and reproductive-tract infections.

The health regressions in this study strongly support the consensus view of Sundarban women that prawn PL collection entails significant health hazards (Table 7 and Figure 7a). Table 7 shows that years of engagement in prawn PL collection has a highly significant, positive impact on the probability of reporting an ailment, while no significance attaches to the estimated effects for years of crabbing, fishing, or engagement in agriculture. Alongside the health impact of saline immersion, Table 7 and Figure $7 \mathrm{~b}$ indicate another significant health impact from ingestion of saline drinking water. Various micro-level research papers have recently assessed the salinity of drinking water in the coastal region of Bangladesh and its impact on hypertension in pregnant women (Khan et al., 2008, 2011; Vineis et al., 2011; Scheelbeek et al., 2016; Naser et al., 2019). These studies draw on numerous international observational studies and clinical trials that establish a strong link between higher salt intake and elevated blood pressure (Calabrese \& Tuthill, 1981; Hallenbeck et al., 1981; Welty et al., 1986; Midgley et al., 1996; He \& MacGregor, 2007; Alderman, 2000). The findings of the present research on adverse health impacts of drinking water salinity are in line with this recent literature (Khan et al., 2008, 2011; Scheelbeek et al., 2016; Naser et al., 2019).

One potentially-important caveat should be acknowledged. The ailments data in this study are all self-reported 
and, as previously noted, women's occupational choices are conditioned by differential expectations about the health consequences. It is therefore possible that the significant result for the impact of prawn PL collection on health is auto-generated by prior expectations: Women expect to get sicker when they engage in prawn PL collection, and they perceive more ailments as a result. While this possibility exists, its importance should be discounted for three reasons. The first is empirical. The findings indicate that the significant impacts of prawn PL collection on health are limited to very few ailments among many. It is difficult to believe that a "folkloric" association between prawn PL collection and health would be so confined. The second reason is methodological. Even if each patient were examined by a doctor, the examination results would inevitably reflect self-reported symptoms to a large degree (Note 2). It is therefore not clear that the results of this study could have been tightened, even if the requisite resources had been available. The third reason is psychological. Ultimately, what is the difference between being sick and thinking one is sick? For an affected individual, the attendant suffering is equally real.

\subsection{The Role of Education}

The empirical analysis may also shed light on the broader role of education in this context. A priori, it seems reasonable to suppose that education has two impacts on female health. The first, clearly supported by the results of this study, operates through the opportunity wage. Poorly-educated women with no access to higher-wage jobs frequently opt for prawn PL collection, while their better-educated counterparts do not. One might also expect an additional education effect in the health equation, based on the argument that educated women improve their health in other ways. However, the results register an educational effect on health only through occupational choice. The larger implications of this finding cannot be judged, since survey data rarely include occupational health as an intermediating factor between female employment choices and health outcomes. In this case, the results suggest that poor health is the result of adverse economic choices rather than a by-product of poor education.

The results may also provide some insights for policy. Figure 6 was produced by fitting a spline regression to the relationship between female age and education in the survey data. The result revealed striking educational progress in the Sundarban region. Predicted years of education decline steeply with age: 9 years at age 20, 6 years at 30,4 years at 40 , and 2 years at 60 . Given the powerful impact of education on engagement in prawn PL collection, it seems reasonable to predict a rapid decline in engagement as younger, better-educated cohorts progressively dominate the female labor force.

\subsection{Prospects for Improved Livelihoods}

If the current education-induced trend holds, the future locus of ill-health will be in older-age cohorts, which will decline in numbers with the passage of time. But this does not imply that the health damage problem associated with prawn PL collection will be "solved" by the passage of time, since many thousands of older women will remain affected. In addition, a simple trend analysis cannot provide useful insights for policy measures that could improve the livelihoods of women who remain in prawn PL collection.

Environmental sustainability seems likely to play a significant future role in policy-making, since recent research has documented the roles of salinization and overfishing in the decline of prawn PL collection. Water salinity in the Indian Sundarban is rising as climate change affects river flows and sea level. Salinity is already near marine levels in southern areas, with measures of 30 parts per thousand (ppt) or higher. By 2050, regional salinity will intensify considerably, with many northern areas also surpassing 30 ppt (Dasgupta, 2017; Dasgupta et al., 2017; Mukhopadhyay et al., 2019). Therefore, climate change may also affect the availability of tiger prawn seedlings and the extent of prawn PL collection in the future.

Overfishing has also played an environmentally-damaging role in the Sundarban, both for prawn PL (Mahapatra et al., 1999; Ahamed et al., 2012) and other species that are discarded in the process (Chandra \& Sagar, 2003). Future sustainability will depend on managing the overall prawn PL catch within ecologically-sustainable limits in areas that remain free of salinization.

The issue of environmental sustainability highlights the need for policy interventions that promote community management of prawn PL resources. Community management could strengthen the position of fishing women in bargaining relationships with agents who purchase the prawn PL for commercial operations. In addition, community-level organization could improve the financial prospects of prawn PL collectors by reducing their need to borrow from private lenders as their incomes fluctuate with variable catch volumes (Islam \&Chuenpagdee, 2013).Such improvements could be realized by community credit programs arranged with financial organizations operating under India's new Corporate Social Responsibility (CSR) framework (Note 3).Such programs could also finance safer and more productive techniques for capturing wild prawn PL if they 
existed, but extensive inquiries in Sundarban by one of the authors have not identified any currently-available options.

Although community management may have significant potential for improving the livelihoods of women who remain in prawn PL collection, it should be recognized that environmental sustainability will impose a natural limit on the future scale of the sector.

\section{Conclusions}

In light of the research findings, an abbreviated SWOT (strengths, weaknesses, opportunities, threats) analysis (Humphrey, 2005) can be used to summarize the current status and future prospects of Sundarban women who are engaged in prawn PL collection.

Strengths: Prawn PL collectors have open access to a widely-distributed, high-demand resource at the base of a sustainable value chain that produces significant profits for investors. An additional advantage is offered by self-determined employment hours, which allow time for household responsibilities and other transient employment opportunities that may arise.

Weaknesses: In the current system, prawn PL collection by individual women involves hard labor with a low payoff under hazardous environmental conditions that increase the likelihood of illness from saline immersion and death or injury from crocodile attacks. As such, it operates as an employment of last resort for women whose spatial immobility and low education levels give them few income-earning alternatives. In addition, dependence on prawn PL income, combined with substantial random fluctuations in the prawn PL catch, leads to widespread indebtedness to private credit providers.

Opportunities: Rising levels of education are expanding younger women's opportunities for alternative, higher-payoff employment. The departure of young women from the sector may reduce competition for the older, less-educated women who remain. In addition, the requirements of India's Corporate Social Responsibility statute may reduce women's debt burdens by encouraging the participation of outside financial organizations in community-managed credit systems.

Threats: Two environmental factors may significantly reduce potential earnings in this sector. First, progressive salinization from sea level rise is reducing prawn PL habitat as it advances. Women in the affected areas will ultimately be forced to withdraw from prawn PL collection. Second, individual collection has led to over-exploitation of the natural prawn PL stock, as well as depletion of other aquatic species that are discarded from capture nets. Restoration of ecological balance will require a reduction in the overall scale of collection.

The SWOT analysis provides an abbreviated framework for understanding the tradeoffs faced by Sundarban women who work in prawn PL collection. The results of this study suggest that women are commonly aware of the health risks from prawn PL collection, and engagement in this activity is heavily concentrated among those with low opportunity wages whose time is not preempted by child-care demands. The results also support the women's general view of health risks. Controlling for otherwise-similar occupational choices, individual/household characteristics, and saline water ingestion, the econometric estimates indicate that more years of saline exposure in prawn PL collection entail greater health risks. It should be acknowledged that the ailments analyzed in this paper are self-reported. However, understanding women's beliefs about the association is also important because their risk perception influences decisions about whether and how much to engage in saline-immersive activities.

The research findings highlight education as a major factor in determining women's occupational choices. They also suggest that educational progress will reduce the number of women who collect prawn PL in the coming years. However, many thousands of older, less-educated women will remain engaged for the foreseeable future.

The areas where collection of prawn PL is still prevalent are remote from market centers and offer few alternative occupations for less-educated women. In contrast, women elsewhere in the Sundarban, with better transport facilities and access to markets, have participated in training for home-based work alternatives. Examples include food processing, tailoring, and embroidery, which are taught by organizations such as the West Bengal Joygopalpur Gram Vika Kendra (Roy et al., 2017; Biswas \& Ghosh, 2020). More isolated women are not likely to benefit from these options unless more public resources are devoted to improved market access, skills training and subsidized credit.

In conclusion, it should be acknowledged that the findings and policy implications discussed in this paper reflect the specific social, economic and environmental characteristics of Indian's Sundarban region. The paper has direct relevance for prawn PL collection in the Sundarban region of Bangladesh, which operates under similar conditions (Islam \& Chuenpagdee, 2013). Although wild prawn PL collection previously played an important 
role in other Asian countries (e.g., Kungvankij, 1984) on Thailand, Malaysia, Singapore, Indonesia and Philippines), commercial spawning has supplanted wild collection as development has raised opportunity wages in those economies (Nadarajah \& Eide, 2020). For other cases involving occupational choices and environmental health hazards for marginalized people, it is hoped that the methods employed for this research will provide a model for future investigations.

\section{Acknowledgments}

This research was funded by the South Asia Water Initiative, Sundarban Targeted Environmental Studies Trust Fund, administered by the World Bank. We are thankful to Sreejit Roy, Saptarsi Chakraborty, Tapas Kumar Sutradhar, AshokeTaru Mondal, Tirthankar Mondal, and Braja Sourav Chattopadhyay for their help with the focus group discussions and the household survey. We are grateful to Md. Istiak Sobhan and Paritosh Giri for providing the photographs. The findings, interpretations, and conclusions expressed in this paper are entirely those of the authors. They do not necessarily represent the views of the International Bank for Reconstruction and Development/World Bank and its affiliated organizations, or those of the Executive Directors of the World Bank or the governments they represent.

\section{References}

Ahamed, F., Hossain, M. Y., Fulanda, B., Ahmed, Z. F., \& Ohtomi, J. (2012). Indiscriminate exploitation of wild prawn postlarvae in the coastal region of Bangladesh: A threat to the fisheries resources, community livelihoods and biodiversity. Ocean \& Coastal Management, 66, 56-62. https://doi.org/10.1016/j.ocecoaman.2012.05.025

Alderman, M. H. (2000). Salt, Blood Pressure, and Human Health. Hypertension, 36(5), 890-893. https://doi.org/10.1161/01.HYP.36.5.890

Asai, Y., Kambayashi, R., \& Yamaguchi, S. (2015). Childcare availability, household structure, and maternal employment. Journal of the Japanese and International Economies, 38, 172-192. https://doi.org/10.1016/j.jjie.2015.05.009

Banerjee, B. K., \& Singh, H. (1993). The shrimp fry by-catch in West Bengal. FAO Bay of Bengal Programme. Madras, India: Central Institute of Brackish Water Aquaculture. Retrieved from http://www.fao.org/3/ae467e/ae467e00.pdf

Biswas, P., \& Ghosh, S. (2020). Tiger widows of Sunderbans: In the shadow of mangroves, tale of courage and hope. Indian Express. Retrieved February 14, 2020, from https://indianexpress.com/article/india/tiger-widows-of-sunderbans-in-the-shadow-of-mangroves-late-of-co urage-and-hope-6268496/

Calabrese, E. J., \& Tuthill, R. W. (1981). The influence of elevated levels of sodium in drinking water on elementary and high school students in Massachusetts. Science of the Total Environment, 18, 117-133. https://doi.org/10.1016/S0048-9697(81)80054-X

Chandra, G., \& Sagar, R. L. (2003). Fisheries in Sundarbans: Problems and Prospects. SSRN Electronic Journal. https://doi.org/10.2139/ssrn.2084014

Dasgupta, S. (2017). Increasing Salinity in a Changing Climate Likely to Alter Sundarban's Ecosystem. World Bank. Retrieved January 22, 2017, from https://www.worldbank.org/en/news/feature/2017/01/22/increasing-salinity-in-a-changing-climate-likely-toalter-Sundarban-ecosystem

Dasgupta, S., Huq, M., Mustafa, M. G., Sobhan, M. I., \& Wheeler, D. (2017). The Impact of Aquatic Salinization on Fish Habitats and Poor Communities in a Changing Climate: Evidence from Southwest Coastal Bangladesh. Ecological Economics, 139, 128-139. https://doi.org/10.1016/j.ecolecon.2017.04.009

Government of India. (2011a). District Census Handbook: North Twenty-Four Parganas. Retrieved from https://censusindia.gov.in/2011census/dchb/1911_PART_B_DCHB_NORTH\%20TWENTY\%20FOUR\%20 PARGANAS.pdf

Government of India. (2011b). District Census Handbook: South Twenty-Four Parganas. Retrieved from https://censusindia.gov.in/2011census/dchb/1917_PART_B_DCHB_SOUTH\%20TWENTY\%20FOUR\%20 PARGANAS.pdf

Hagiwara, R. (2016). The Effect of Childcare Cost on Female Labor Supply and Use of Childcare Service. International Journal of Economic Policy Studies, 11(1), 43-63.https://doi.org/10.1007/BF03405765 
Hallenbeck, W. H., Brenniman, G. R., \& Anderson, R. J. (1981). High Sodium in Drinking Water and Its Effect on Blood Pressure. American Journal of Epidemiology, 114(6), 817-826. https://doi.org/10.1093/oxfordjournals.aje.a113252

He, F. J., \& MacGregor, G. A. (2007). Salt, blood pressure and cardiovascular disease. Current Opinion in Cardiology, 22(4), 298-305. https://doi.org/10.1097/HCO.0b013e32814f1d8c

Humphrey, A. (2005). SWOT analysis for management consulting. SRI alumni Newsletter, 1, 7-8.

Islam, M. M., \& Chuenpagdee, R. (2013). Negotiating risk and poverty in mangrove fishing communities of the Bangladesh Sundarbans. Maritime Studies, 12(1). https://doi.org/10.1186/2212-9790-12-7

Jena, M. (2018). Women in India Face Health Problems and Other Risks as the Rivers Grow Saltier. Global Citizen. Retrieved from https://www.globalcitizen.org/en/content/women-india-water-saltier/

Khan, A., Mojumder, S. K., Kovats, S., \& Vineis, P. (2008). Saline contamination of drinking water in Bangladesh. The Lancet, 371(9610), 385. https://doi.org/10.1016/S0140-6736(08)60197-X

Khan, A. E., Ireson, A., Kovats, S., Mojumder, S. K., Khusru, A., Rahman, A., \& Vineis, P. (2011). Drinking Water Salinity and Maternal Health in Coastal Bangladesh: Implications of Climate Change. Environmental Health Perspectives, 119(9), 1328-1332. https://doi.org/10.1289/ehp.1002804

Kornstad, T., \& Thoresen, T. O. (2007). A discrete choice model for labor supply and childcare. Journal of Population Economics, 20(4), 781-803.https://doi.org/10.1007/s00148-005-0025-z

Kungvankij, P. (1985). Overview of penaeid shrimp culture in Asia. In Proceedings of the First International Conference on the Culture of Penaeid Prawns/Shrimps, 4-7 December 1984, Iloilo City, Philippines (pp. 11-21). Aquaculture Department, Southeast Asian Fisheries Development Center. Retrieved from https://repository.seafdec.org.ph/bitstream/handle/10862/881/ficcpps_p011-021.pdf

Mahapatra, B. K., Chatterjee, P., Saha, D., \& Datta, N. C. (1999). Declining trend in the abundance of seeds of tiger shrimps, Panaeusmonodon (fabricus) in the Sundarbans with suggestion for restorations. Sundarbans Mangal, 532-538.

Midgley, J. P., Matthew, A. G., Greenwood, C. M. T., \& Logan, A. G. (1996). Effect of reduced dietary sodium on blood pressure: A meta-analysis of randomized controlled trials. JAMA: The Journal of the American Medical Association, 275(20), 1590-1597. https://doi.org/10.1001/jama.275.20.1590

Mukhopadhyay, A., Wheeler, D., Dasgupta, S., Dey, A., \& Sobhan, I. (2019). Mangrove Spatial Distribution in the Indian Sundarbans: Predicting Salinity-Induced Migration in a Changing Climate. Journal of Management and Sustainability, 9(1), 1. https://doi.org/10.5539/jms.v9n1p1

Nadarajah, S., \& Eide, A. (2020). Are Asian fresh and brackish water aquaculture production vulnerable or resilient towards climate change impacts? Aquaculture Economics \& Management, 24(3), 232-254. https://doi.org/10.1080/13657305.2019.1677802

Naser, A. M., Rahman, M., Unicomb, L., Doza, S., Gazi, M. S., Alam, G. R., ... Clasen, T. F. (2019). Drinking Water Salinity, Urinary Macro - Mineral Excretions, and Blood Pressure in the Southwest Coastal Population of Bangladesh. Journal of the American Heart Association, 8(9). https://doi.org/10.1161/JAHA.119.012007

Roy, A., Sharma, A., Bhaumik, U., Pandit, A., Singh, S., Saha, S., \& Mitra, A. (2017). Socio-economic Features of Womenfolk of Indian Sunderbans Involved in Fish Drying. Indian Journal of Extension Education,53(2), $142-146$.

Scheelbeek, P. F. D., Khan, A. E., Mojumder, S., Elliott, P., \& Vineis, P. (2016). Drinking Water Sodium and Elevated Blood Pressure of Healthy Pregnant Women in Salinity-Affected Coastal Areas. Hypertension, 68(2), 464-470. https://doi.org/10.1161/HYPERTENSIONAHA.116.07743

Vineis, P., Chan, Q., \& Khan, A. (2011). Climate change impacts on water salinity and health. Journal of Epidemiology and Global Health, 1(1), 5. https://doi.org/10.1016/j.jegh.2011.09.001

Welty, T. K., Freni-Titulaer, L., Zack, M. M., Weber, P., Sippel, J., Huete, N., ... Murphy, M. A. (1986). Effects of exposure to salty drinking water in an Arizona community. Cardiovascular mortality, hypertension prevalence, and relationships between blood pressure and sodium intake. JAMA: The Journal of the American Medical Association, 255(5), 622-626. https://doi.org/10.1001/jama.255.5.622 


\section{Notes}

Note 1. Significant commercial prawn species includePanaeusmonodon (giant tiger prawn), Panaeuspenicullatus (redtail prawn) and Metapenaeusmonoceros (speckled shrimp). The two edible crab species are Scylla serrata (mangrove crab) and Neptunuspelagiens. Important commercial fish species include Tenualosailisha, Liza parsia, Planilizatade, Harpadonnehereus, Plotosuscanius, Pampusargenteus, Rhinobatosannandalei, Pangasiuspangasius, Polydactylusindicus, Chanoschanos, Eleutheronematetradactylum, Polynemousindicus, Polynemousparadiseus and Pamapama (Chandra \& Sagar, 2003).

Note 2. The health-care facilities in the remote Sundarban locations are abysmally poor. In nearly all of the survey sites, no trained physician was available for regular consultations. In a few locales with reasonable road infrastructure, physicians were available for consultation at local pharmacies on fixed days of the week. Occasionally, medical camps are arranged by non-governmental organizations (NGOs).

Note 3. Under the Indian Companies Act of 2013, Corporate Social Responsibility imposes a statutory requirement to promote social welfare activities.

\section{Appendix A}

\section{Locational Distribution of Survey Sample}

\begin{tabular}{|c|c|c|c|c|}
\hline Block & Gram Panchayat & Hamlet & Total no. of households listed & Total no. of sample selected \\
\hline \multirow[t]{5}{*}{ Basanti } & \multirow[t]{5}{*}{ Jharkhali } & NeheruPalli & 98 & 16 \\
\hline & & Jharkhali $5 \& 6$ No. & 47 & 10 \\
\hline & & Shahidnagar & 43 & 11 \\
\hline & & Adibasi Para & 51 & 15 \\
\hline & & Tridibnagar & 40 & 9 \\
\hline \multirow[t]{16}{*}{ Gosaba } & \multirow[t]{4}{*}{ Bali-I } & Lombapara & 60 & 13 \\
\hline & & 1 No Para & 60 & 17 \\
\hline & & 4 No Para & 61 & 15 \\
\hline & & Satyanarayanpur & 60 & 15 \\
\hline & \multirow[t]{4}{*}{ Kumirmari } & Bhrulia Para & 60 & 15 \\
\hline & & Forest Office Para & 60 & 15 \\
\hline & & Kayal Para & 120 & 15 \\
\hline & & Office Para & 59 & 15 \\
\hline & \multirow[t]{4}{*}{ Lahiripur } & Kartikkhali & 50 & 10 \\
\hline & & Patharpara & 51 & 19 \\
\hline & & Tripligheri & 54 & 19 \\
\hline & & Sadhupur-Banikhali & 59 & 12 \\
\hline & \multirow[t]{4}{*}{ Rangabelia } & Brojomahendra H.S. Para & 60 & 24 \\
\hline & & JatirampurPurbaDakkhinpara & 60 & 13 \\
\hline & & Tripligheri & 60 & 11 \\
\hline & & PakhiralaDakkhinpara & 60 & 12 \\
\hline \multirow[t]{4}{*}{ Hingalganj } & Kalitala & Kalindi Para & 60 & 21 \\
\hline & \multirow[t]{3}{*}{ Sahebkhali } & Bhuniapara & 54 & 21 \\
\hline & & Karikorpara & 60 & 9 \\
\hline & & MantrirghatDaspara & 46 & 9 \\
\hline \multirow[t]{6}{*}{ Kultali } & \multirow[t]{6}{*}{ Gopalgunj } & Haribhasha & 59 & 10 \\
\hline & & Paschim Para & 60 & 9 \\
\hline & & PurbaGopalgunj & 59 & 11 \\
\hline & & Naskar Para & 59 & 11 \\
\hline & & Khalagheri & 40 & 10 \\
\hline & & Naskar Para & 60 & 9 \\
\hline \multirow[t]{3}{*}{ Namkhana } & \multirow[t]{3}{*}{ Frezergunj } & Paschim Para & 60 & 21 \\
\hline & & DakhsinPaschim Para & 60 & 17 \\
\hline & & PaschimVijaybati & 60 & 22 \\
\hline \multirow[t]{6}{*}{ Patharpratima } & \multirow[t]{4}{*}{ Achintyanagar } & Mallik Para & 60 & 13 \\
\hline & & Kachari Para & 60 & 16 \\
\hline & & Maitypara & 60 & 18 \\
\hline & & Molla Para & 60 & 13 \\
\hline & \multirow[t]{2}{*}{ Brajaballavpur } & Colony Para & 60 & 6 \\
\hline & & Uttar-Purba Para & 60 & 14 \\
\hline
\end{tabular}




\begin{tabular}{|c|c|c|c|c|}
\hline & & Majherpara & 60 & 19 \\
\hline & \multirow{6}{*}{ G-Plot } & Adibasipara (Madhyopara) & 20 & 5 \\
\hline & & Modhyopara & 20 & 8 \\
\hline & & Muslimpara (Modhyopara) & 20 & 8 \\
\hline & & Shikari Para & 60 & 6 \\
\hline & & GobordhanpurDakshin Para & 60 & 17 \\
\hline & & Paschim Para & 60 & 20 \\
\hline & \multirow{3}{*}{ Gopalnagar } & Daspara & 60 & 17 \\
\hline & & Mandal Para & 40 & 15 \\
\hline & & Pradhan Para & 59 & 14 \\
\hline & \multirow{5}{*}{ Patharpratima } & Shyamal Para & 20 & 15 \\
\hline & & Tunga Para & 58 & 16 \\
\hline & & Jana Para & 20 & 11 \\
\hline & & Samanta Para & 20 & 14 \\
\hline & & Samanta-Jana Para & 20 & 15 \\
\hline & & Baruipara & 60 & 20 \\
\hline & Shridharnagar & Giri Para & 60 & 15 \\
\hline \multirow{6}{*}{ Sagar } & & Jana Para & 60 & 14 \\
\hline & & Kayalpara & 60 & 12 \\
\hline & & Natungheri & 60 & 19 \\
\hline & $\begin{array}{l}\text { Dhaspara-Suma } \\
\text { tinagar } 2\end{array}$ & 1 No. Colony & 60 & 20 \\
\hline & & 2 No. Colony & 60 & 19 \\
\hline & & Purbapara/Ashrampara & 60 & 21 \\
\hline Total & & & 3,447 & 901 \\
\hline
\end{tabular}

\section{Appendix B}

Sundarban Survey Locales: Percent of Working-age Women in Prawn PL Collection, Crabbing, and Fishing

\begin{tabular}{|c|c|c|}
\hline Gram Panchayat_Hamlet & Women surveyed (ages 15-65+) & Main occupation prawn PL/fish/crab catcher (\%) \\
\hline Achintyanagar_Molla Para & 26 & 0.0 \\
\hline Gopalnagar_Pradhan Para & 28 & 0.0 \\
\hline Jharkhali $5 / 6$ No. Sahidnagar & 10 & 0.0 \\
\hline Lahiripur Kartikkhali & 13 & 0.0 \\
\hline Lahiripur SadhupurBanikhali & 12 & 0.0 \\
\hline Rangabelia Jotirampur Purba Dakshin Para & 3 & 0.0 \\
\hline Gopalnagar_Shyamal Para & 33 & 3.0 \\
\hline Rangabelia_Brajamahendrapur High School Para & 29 & 3.5 \\
\hline Sridharnagar_Jana Para & 27 & 3.7 \\
\hline Achintyanagar_Maity Para & 26 & 3.9 \\
\hline Dhaspara Sumatinagar- II_Purba Para & 23 & 4.4 \\
\hline Sahebkhali_Karikar Para & 20 & 5.0 \\
\hline Bali-1_Lomba Para & 19 & 5.3 \\
\hline Rangabelia_PakhiralaDakshin Para & 34 & 5.9 \\
\hline G-Plot_Das Para & 15 & 6.7 \\
\hline Achintyanagar_Kachari Para & 13 & 7.7 \\
\hline G-Plot_GobordhanpurDakshin Para & 12 & 8.3 \\
\hline G-Plot_IndrapurPaschim Para & 36 & 8.3 \\
\hline Brajaballavpur_Majher Para & 34 & 8.8 \\
\hline Rangabelia_Tripligheri & 11 & 9.1 \\
\hline Jharkhali_Neherupalli & 20 & 10.0 \\
\hline Bali-1_1 No. Para & 25 & 12.0 \\
\hline Frazerganj_DakshinPaschim Para & 8 & 12.5 \\
\hline Gopalnagar_Mandal Para & 24 & 12.5 \\
\hline Achintyanagar_Mallik Para & 15 & 13.3 \\
\hline G-Plot_Shikari Para & 7 & 14.3 \\
\hline Bali-1_Satyanarayanpur & 19 & 15.8 \\
\hline Lahiripur_Tripligheri & 25 & 16.0 \\
\hline Kalitala_Kalindi Para & 30 & 16.7 \\
\hline Kumirmari_Kayal Para & 18 & 16.7 \\
\hline Sahebkhali_Mandirghat Das Para & 6 & 16.7 \\
\hline Patharpratima_Jana Para - Samanta Para & 82 & 19.5 \\
\hline Gopalganj_Haribhasa & 25 & 20.0 \\
\hline Jharkhali_Adibasi Para & 25 & 20.0 \\
\hline
\end{tabular}




\begin{tabular}{lll}
\hline Sahebkhali_Bhunia Para & 34 & 20.6 \\
Dhaspara Sumatinagar- II_1 No. Colony & 29 & 20.7 \\
Kumirmari_Bhrulia Para & 19 & 21.1 \\
Frazerganj_Paschim Para & 35 & 22.9 \\
Gopalganj_Paschim Para & 17 & 23.5 \\
Bali-1_4 No. Para & 21 & 23.8 \\
Dhaspara Sumatinagar- II_2 No. Colony & 33 & 24.2 \\
Kumirmari_Forest Office Para & 19 & 26.3 \\
Patharpratima_Barui Para & 34 & 26.5 \\
Jharkhali_Tridibnagar & 11 & 27.3 \\
Gopalnagar_Tunga Para & 23 & 30.4 \\
Sridharnagar_Kayal Para & 22 & 31.8 \\
Frazerganj_PaschimVijaybati & 33 & 33.3 \\
Jharkhali_7/8 No. Sahidnagar & 20 & 35.0 \\
Kumirmari_Office Para & 16 & 37.5 \\
Gopalganj_Naskar Para & 41 & 39.0 \\
Brajaballavpur_Adibasi Para (Modhyo Para) & 12 & 50.0 \\
Brajaballavpur_Modhyo Para & 10 & 50.0 \\
Lahiripur_Pathar Para & 20 & 50.0 \\
Sridharnagar_Natungheri & 14 & 50.0 \\
Sridharnagar_Giri Para & 25 & 52.0 \\
\hline
\end{tabular}

\section{Copyrights}

Copyright for this article is retained by the author, with first publication rights granted to the journal.

This is an open-access article distributed under the terms and conditions of the Creative Commons Attribution license (http://creativecommons.org/licenses/by/4.0/). 